\title{
Perlindungan Hukum Terhadap Konsumen Pada Perjanjian Jual Beli Sepeda Motor Studi Kasus Di Bima
}

\author{
Ahmadin \\ STKIP Taman Siswa Bima \\ Email: bimaahmadin13@gmail.com
}

\begin{abstract}
Abstrak. Tujuan dalam penelitian ini adalah agar Dapat mengetahui bagaimana masyarakat yang tidak mampu atau memaksakan diri untuk membeli sepeda motor secara tunai, yang biasanya menggunakan jasa perusahaan pembiayaan dan perusahaan pembiayaan dalam menyelenggarakan pembiayaan sepeda motor dengan menggunakan model perjanjian baku, yaitu perjanjian yang bentuk maupun isinya telah ditetapkan secara sepihak oleh pihak yang ekonomis atau psikologis lebih kuat. Dan bagi para pengusaha penggunaan perjanjian baku ini mungkin merupakan cara mencapai tujuan ekonomis yang efisien dan praktis karena perjanjian tersebut digunakan atau di berlakukan pada setiap calon konsumen. Desain penelitian ini merupakan penelitian hukum yuridis empiris. Penelitian ini dilakukan dengan cara mengkaji dan mengolah data-data yang diperoleh dilapangan yang merupakan data primer atau yang disebut juga penelitian lapangan dengan bertitik tolak aspek hukum (yuridis). Untuk mendukung dan melengkapi data primer juga dilakukan penelitian kepustakaan guna memperoleh data sekunder tentang permasalahan yang diteliti. Dengan demikian data yang digunakan dalam penelitian ini adalah data primer dan data sekunder. Penelitian ini bersifat deskriptif analitis. Deskriptif artinya karena hasil penelitian ini diharapkan dapat memberikan gambaran sistematis, terperinci dan menyeluruh mengenai pelaksanaan perjanjian jual beli angsuran sepeda motor di Bima. Analitis artinya karena untuk selanjutnya akan digunakan untuk menjawab permasalahan yang kedua yakni perlindungan hukum terhadap konsumen pada perjanjian jual beli sepeda motor. Hasil penelitiannya adalah Dalam hal leavering atau penyerahan, KUHPerdata megandung sistem causal yaitu suatu sistem yang menggantungkan sahnya leavering itu pada dua syarat. a.) sahnya titel yang menjadi dasar dilakukannya leavering; dan b.) leavering tersebut dilakukan oleh orang yang berhak berbuat bebas (beschikingsbevoegd) terhadap barang yang dileaver itu. Disini titel yang menjadi dasar leavering itu, yakni jual beli, tukar menukar, hibah (tiga perjanjian ini merupakan titel-titel untuk memindahkan hak milik). adapun orang yang berhak berbuat bebas adalah pemilik barang sendiri atau orang yang dikuasakan olehnya. Selama ini pemahaman yang ada dimasyarakat mengenai jual beli angsuran, sewa beli dan leasing adalah sama yakni pembayarannya yang dilakukan secara berkala. Namun, pengertian antara jual beli angsuran, sewa beli dan leasing berbeda.
\end{abstract}

Kata kunci: Perlindungan, Konsumen Dan Sepeda Motor.

\section{PENDAHULUAN}

Permintaan kebutuhan akan sepeda motor sebagai alat transportasi dirasakan terus mengalami peningkatan. Dengan meningkatnya jumlah pembeli sepeda motor pada setiap tahun disebabkan oleh perubahan pola atau gaya hidup masyarakat yang cenderung materialistik dan konsumtif. Akan tetapi masyarakat tentu mempunyai kebutuhan akan barang dan jasa dan kebanyakan tidak mengukur sesuai dengan penghasilan.
Masyarakat yang tidak mampu atau memaksakan diri untuk membeli sepeda motor secara tunai, biasanya menggunakan jasa perusahaan pembiayaan dan perusahaan pembiayaan dalam menyelenggarakan pembiayaan sepeda motor dengan menggunakan model perjanjian baku, yaitu perjanjian yang bentuk maupun isinya telah ditetapkan secara sepihak oleh pihak yang ekonomis atau psikologis lebih kuat. Bagi para pengusaha penggunaan perjanjian baku ini mugkin merupakan cara mencapai tujuan ekonomis yang efisien dan praktis karena 
perjanjian tersebut digunakan atau di berlakukan pada setiap calon konsumen.

Penggunaan Perjanjian baku dalam dunia bisnis tampaknya telah menjadi hal yang biasa dilakukan oleh pelaku usaha. Namun, penjanjian baku sendiri secara teoritis masih mengundang perdebatan, khususnya dalam kaitannya dengan unsur kebebasan berkontrak dan syarat sahnya perjanjian dalam hal kesepakatan. Didalam perjanjian baku, kebebasan untuk melakukan perjanjian serta pemberian kesepakatan terhadap perjanjian tersebut tidak dilakukan sebebas dengan perjanjian yang dilakukan secara langsung dengan melibatkan para pihak dalam menegosiasikan klausula perjanjian.

Dalam prakteknya perusahaan pembiayaan akan menyodorkan formulir (form) perjanjian yang telah dipersiapkan sebelumnya kepada calon konsumen. Dalam hal ini konsumen hanya dihadapkan pada dua pilihan yaitu menerima perjanjian dengan syarat-syarat yang telah ditetapkan oleh pengusaha atau menolaknya jika tidak menyetujuinya. Singkatnya “ jikan konsumen membutuhkan silahkan ambil atau jika keberatan tinggalkan saja (take it or leave it)" (muhammad, 1992: 3). Posisi ini jelas tidak menguntungkan bagi konsumen karena jika ia beralih ke perusahaan pembiayaan lain, konsumen juga akan dihadapakan pada model perjanjian yang sama. Oleh karena konsumen membutuhkan sepeda motor maka ia terpaksa menerima perjanjian tersebut dengan segala persyaratan yang telah ditentukan oleh perusahaan pembiayaan.

Perusahaan pembiayaan dalam menyelenggarakan pembiayaaan sepeda motor antara perusahaan pembiayaan satu atau dengan yang lainnya berbeda dalam penyebutan perjanjiannya. Ada yang menyebutkan sebagai sewa beli leasing maupun perjanjian pembiayaan bersama. Akan tetapinsatu hal yang sama diantara perjanjian tersebut adalah perikatan jaminannya yaitu dengan jaminan fidusia.

Lembaga jaminan fidusia ini diatur dalam undang-undang nomor 42 tahun 1999 tentang jaminan fidusia. Jaminan fidusia menrupakan pengalihan hak milik secara kepercayaan, artinya bahwa objek jaminan itu tetap berada pada pemberi fidusia (debitur) dan yang dialihkan adalah hak miliknya secara kepercayaan yaitu sebagai jaminan hutang debitur. Lembaga jaminan fidusia, menaratkan bahwa untuk dapat diikat dengan jamina fidusia maka benda yang menjadi objek jaminan tersebut adalah milik dari pemberi fidusia. Selain itu objek jaminan fidusia merupakan benda bergerak baik yang berwujud maupun tidak berwujud atau benda tidak bergerak khususnya bangunan yang tidak dapat dibebani hak tanggungan.

Maka jika mengacu pada peralihan hak miliknya yang sudah beralih pada pembeli maka hal tersebut tidak sesuai dengan pengertian sewa beli maupun leasing. Pada sewa beli hak milik masih beada pada penjual sampai barang tersebut dibayar lunas. Sedangkan pada leasing hak milik tetap berada pada leassor sampai ahir perjanjian leasing. Dan hak milik beralih pada lessee membeli dengan harga (financial lease). Selain itu menjadi objek leasing adalah barang modal atau alat produksi.

Berbeda halnya dengan jual beli angsuran, pada jual beli angsuran hak milik itu sudah beralih pada saat barang itu diserahkan kepada pembeli walaupun barang tersebut belum dibayar lunas. Berdasarkan alasan tersebut maka perjanjian pembiayaan sepeda motor, yang diikat dengan jaminan fidusia lebih tepat dikatakan sebagai jual beli angsuran yang menempatan pembeli sebagai pemilik benda. Secara populer jika membutuhkan sepeda motor dengan perjanjian jual beli angsuran dikenal dengan istilah kredit motor. Praktek sederhananya perusahaan pembiayaan menyediakan sepeda motor sesuai spesifikasi yang diinginkan konsumen. Setelah sepeda motor diserahkan kepada konsumen maka konsumen membayar harga sepeda motor ditambah bunga serta biaya-biaya lainnya kepada perusahaan pembiayaan dengan cara diangsur atau secara berkala. Konsekuensinya maka debitur sebagai pemilik barang ( pemberi fidusia) kemudian menyerahkan hak miliknya secara kepercayaan kepada kreditur (penerima fidusia) yakni sebagai jaminan pelunasan hutang. 
Pengalihan hak milik secara kepercayaan dalam jaminan fidusia dituangkan dalam akta pembebanan jaminan fidusia yang dibuat oleh notaris. Akta pembebanan jaminan fidusia kemudian didaftarkan ke kanwil departemen hukum dan hak asasi manusia. Pendaftaran jaminan fidusia merupakan jaminan dari penerima fidusia kuasa atau wakilnya. Setelah dilakukan pendaftaran sebagai bukti bahwa kreditur sebagai pemegang fidusia akan mendapatkan sertifikat jaminan fidusia.

Sertifikat jaminan fidusia ini mempunyai kekuatan hukum yang sama dengan putusan pengadilan yang telah mempunyai kekuatan hukum tetap. Apabila debitur cedera janji atau tidak dapat membayar angsuran tepat pada waktunya dan telah diberikan somasi maka debitur (penerima fidusia) dapat mengeksekusi jaminan fidusia yaitu dengan penyitaan dan penjualan benda yang menjadi objek jaminan fidusia melalui pelelangan umum. Pada jaminan fidusia berkedudukan penerima fidusia adalah kreditur preferen. Kreditur preferen ini mempunyai hak untuk "mengambil pelunasan hutang atau hasil eksekusi objek jaminan lebih dahulu dari pada kreditur lainnya" (salim, 2005:89). Apabila dari hasil penjualan objek jaminan tersebut setelah dikurangi dari hutang debitur terdapat sisa maka kelebihan itu adalah hak debitur.

Dalam pelaksanaannya seringkali konsumen yang telah sekian lama membayar dalam angsuran dan hanya menyisakan beberapa kali angsuran kemudian karena suatu hal konsumen tidak mampu membayar angsuran sepeda motornya ditarik oleh perusahaan pembiayaan berdasarkan ketentuan perjanjian tidak menuntut hakhaknya untuk dipenuhi. Ini terjadi karena pemahaman masyarakat tentang hukum yang masih rendah. Sementara itu praktek dilapangan ada indikasi bahwa perusahaan pembiayaan dalam menyelenggarakan pembiayaan sepeda motor tidak di daftarkan di kanwil departemen hukum dan hak asasi manusia. Contoh kasus saudara hanafi yang menggugat PT krida finance. Persoalan ini bermula dari pembelian sepeda motor yang diangsur Rp. 670.500 .00 perbulan selama 28 kali angsuran dengan perjanjian pembiayaan konsumen dengan menyerahkan hak milik secara fidusia. Ditengah jalan hanafi tak mampu membayar angsuran sesuai batas waktu yang dijanjikan. Kemudian sepeda motor tersebut ditarik oleh PT Krida finance. Alasan yang digunakan sebagai dasar gugatan antara lain karena tidak adanya sertifikat jaminan fidusia. (http://hukumonline.com).

Asas perjanjian "pacta sun servanda" menyatakan bahwa semua perjanjian yang dibuat secara sah berlaku sebagai undang-undang bagi mereka yang membuatnya, tetap berlaku dan menjadi asas utama dalam hukum perjanjian. Tetapi terhadap perjanjian yang diikat dengan jaminan fidusia yang didaftarkan tidak dapat dilakukan eksekusi secara langsung. Proses eksekusi harus dilakukan dengan cara mengajukan gugatan ke pengadilan hingga keluarnya putusan pengadilan yang mempunyai kekuatan hukum tetap. Melalui instrumen semacam pembiayaan konsumen, memang konsumen yang menginginkan sepeda motor dapat dengan mudah memiliki sepeda motor yang diinginkan. Namun, tidak banyak konsumen yang menyadari bahwa konsekuensi di balik kemudahan yang ditawarkan tersebut menyebabkan konsumen dirugikan. Permasalahan baru timbul kemudian setelah konsumen tidak dapat membayar angsuran sepeda motor dan konsekuensinya sepeda motornya ditarik oleh perusahaan pembiayaan.

Undang-undang nomor 8 tahun 1999 tentang perlindungan konsumen mengatur mengenai larangan pelaku usaha untuk mengambil segala tindakan sepihak yang berkaitan dengan barang yang dibeli oleh konsumen secara angsuran dalam hal ini menarik sepeda motor. Kalaupun penarikan sepeda motor tersebut dilakukan haruslah sesuai dengan ketentuan undang-undang yang berlaku. Untuk itu penulis tertarik untuk melakukan penelitian mengenai hal tersebut dengan judul: "Perlindungan Hukum Terhadap Konsumen Pada Perjanjian Jual Beli Sepeda Motor Studi Kasus Di Bima" 


\section{METODE PENELITIAN}

Mengenai metodelogi penelitian yang digunakan oleh peneliti atau penulis dalam hal ini penelitian mengenai perlindungan hukum terhadap konsumen pada perjanjian jual beli sepeda motor studi kasus di bima merupakan penelitian hukum yuridis empiris. Penelitian ini dilakukan dengan cara mengkaji dan mengolah data-data yang diperoleh dilapangan yang merupakan data primer atau yang disebut juga penelitian lapangan dengan bertitik tolak aspek hukum (yuridis). Untuk mendukung dan melengkapi data primer juga dilakukan penelitian kepustakaan guna memperoleh data sekunder tentang permasalahan yang diteliti. Dengan demikian data yang digunakan dalam penelitian ini adalah data primer dan data sekunder.

Penelitian ini bersifat deskriptif analitis. Deskriptif artinya karena hasil penelitian ini diharapkan dapat memberikan gambaran sistematis, terperinci dan menyeluruh mengenai pelaksanaan perjanjian jual beli angsuran sepeda motor di Bima. Analitis artinya karena untuk selanjutnya akan digunakan untuk menjawab permasalahan yang kedua yakni perlindungan hukum terhadap konsumen pada perjanjian jual beli sepeda motor.

Kemudian tekhnik yang digunakan untuk menentukan responden adalah metode proposive sampling yaitu penentuan sample yang dilakukan tidak secara random (non random sampling) melainkan dengan kriteria dan pertimbangan tertentu oleh peneliti sesuai dengan permasalahan yang diteliti. Kritria tersebut berdasarkan orang yang pernah atau sedang melakukan perjanjian jual beli angsuran sepeda motor di wilayah Bima.

\section{HASIL PENELITIAN}

Berdasarkan dari hasil yang di dapatkan peneliti dengan beberapa responden, dalm hal ini permasalahannya tidak ada yang berbeda yang signifikan, akan tetapi responen mengalami hanya pada angsuran yang tertunda dan macet pembayaran. Dari beberapa ini perlu penulis uraikan aturan yang mengikat sebagaimana yang ada dalam
Undang-Undang dan peraturan lainnya. Misalnya tinjuan tentang perjanjian:

Dalam pasal 1313 Kitab UndangUndang Hukum Perdata menyebutkan bahwa perjanjian adalah suatu perbuatan dengan mana satu orang atau lebih mengikatkan dirinya terhadap satu orang atau lebih. Pengertian perjanjian yang terdapat dalam pasal 1313 KHUPerdata tersebut terlalu luas dan terlalu sempit. Pasal 1313 KUHPerdata dikatakan terlalu luas karena hanya menyebutkan perbuatan saja, misalnya zaakwarneming (pengurusan kepentingan orang lain), yang itu terjadi tampa diperjanjikan terlebih dahulu. Sedangkan yang menimbulkan perjanjian adalah perbuatan-perbuatan hukum yang akibatnya diatur oleh hukum. Selain itu kata perbuatan juga terlalu luas karena mencakup perbuatan yang bergerak dilapangan hukum harta kekayaan dan perkawinan yang tunduk pada ketentuan tersendiri bukan tunduk pada buku III KUHPerdata (Sofwan, 1980: 1).

\section{Pasal 1313 KUHPerdata juga} dikatakan terlalu sempit karena perjanjian itu adalah perbuatan dengan mana satu orang atau lebih mengikatkan diri pada satu orang yang lain. Pernyataan ini seakan-akan merupakan perjanjian sepihak padahal pada umumnya perjanjian itu bersifat timbal balik misanya seperti jual beli. Pendapat salim dan Dunne dalam bukunya Salim (2006: 161) menyatakan bahwa perjanjian adalah satu hubungan hukum antara dua pihak atau lebih berdasarkan kata sepakat untuk menimbulkan akibat hukum. Pendapat ini juga diperkuat oleh prof. Mertokusumo (1999: 110) yang menyatakan bahwa perjanjian adalah hubungan hukum antara dua orang yang bersepakat untuk menimbulkan akibat hukum. Dengan demikian, dapat disimpulkan bahwa perjanjian merupakan suatu hubungan hukum antara dua orang atau lebih yang saling mengikatkan diri untuk menimbulkan akibat hukum.

Buku III KUHPerdata khususnya mengenai perjanjian menganut sistem terbuka, terutama karena asas kebebasan berkontrak "pasal-pasal dalam hukum perjanjian merupakan ketentuan hukum pelengkap yang berarti bahwa pasal-pasal 
tersebut boleh disingkirkan apabila dikehendaki oleh para pihak" (subekti, 1990: 13). Para pihak diberbolehkan membuat ketentuan-ketentuan sendiri yang menyimpang dari pasal-pasal hukum perjanjian. Apabila para pihak tidak mengatur suatu hal tersebut akan tidak mengatur suatu hal dalam perjanjian maka mengenai hal tersebut akan tunduk pada ketentuan undangundang. Dalam perkembangannya asas kebebasan berkontrak seringkali menimbulkan ketidakadilan karena prinsip ini hanya dapat mencapai tujuannya. Bila para pihak memiliki kekuatan tawar menawar yang seimbang. Pada kenyataannya tidak demikian contohnya dalam penggunaan perjanjian baku.

Perjanjian baku tersebut yang notabene disusun sepihak oleh pengusaha tentunya mencantumkan klausul-klausul yang menempatkan kedudukan pengusaha yang lebih tinggi dari pada konsumen. Hak-hak dan kewajiban yang tidak seimbang antara konsumen dengan perusahaan pembiayaan ini tentunya menimbulkan ketidakadilan bagi konsumen. Menurut muhammad, (1992: 3) dalam perjanjian baku, konsumen hanya diharapkan pada dua pilihan yaitu: a). Jika konsumen membutuhkan produksi atau jasa yang ditawarkan kepadanya setujuilah perjanjian dengan syarat baku yang disodorkan oleh pengusaha. Dalam bahasa inggris diungkapkan dengan sebutan take it., atau b). Jika konsumen tidak setuju dengan syarat-syarat baku yang ditawarkan itu janganlah membuat perjanjian dengan pengusaha yang bersangkutan dalam bahasa inggrisnya diungkapkan dengan sebutan leave it. Singkatnya, jika konsumen membutuhkan silahkan ambil, atau jika keberatan tinggalkan saja. (take it or leave it).

Perjanjian baku sering juga disebut dengan istilah kontrak standar. Menurut Mertokusumo (1990: 4) kontrak standar ialah suatu kontrak yang isinya ditentukan secara apriori oleh salah satu pihak yang mempunyai kedudukan yang lebih unggul, sehingga pihak adherent (yang lemah) mau tidak mau terikat. Karena sifat kontrak standar ini. Salah satu pihak merelakan pihak lawan dibebaskan atau dikurangi tanggung jawabnya (exsoneratie clausule) karena dalam kedudukan ekonomi lebih lemah.

Selain tinjauan pada perjanjian juga dilihat pada pembiayaan konsumen. Dalam hal ini, di tengah keterbatasan finansial, perusahaan pembiayaan merupakan salah satu sumber pembiayaan alternatif yang dapat membantu memenuhi kebutuhan masyarakat atas barang-barang konsumtif yang dibutuhkan. Melalui pembiayaan konsumen masyarakat yang tadinya kesulitan untuk membeli barang secara tunai akan dapat teratasi dengan cepat dan mudah. Berdasarkan pasal 1 huruf $\mathrm{g}$ peraturan Menteri Keuangan No. 84/PMK/.012/2006 tentang perusahaan pembiayaan yang dimaksud dengan pembiayaan konsumen adalah kegiatan pembiayaan untuk pengadaan barang berdasarkan kebutuhan konsumen dengan pembayaran secara angsuran.

Pembiayaan konsumen ini pada hakekatnya sama dengan kredit konsumen (cousumer credit). Bedanya hanya terletak pada lembaga yang membiayainya. “ pembiayaan konsumen di biayai oleh perusahaan pembiayaan sedangkan kredit konsumen dibiayai oleh bank" (sunaryo, 2008: 96). Dilihat dari aspek jaminan "lembaga pembiayaan dalam melakukan pembiayaan tidak menekankan aspek jaminan (non collateral basis) karena unit yang dibiayai merupakan objek jaminan" (sunaryo, 2008: 15). Ini terjadi karena "pada pembiayaan konsumen pemilikan barang/objek pembiayaan berada pada konsumen yang kemudian diserahkan secara fidusia kepada perusahaan pembiayaan" (Rahmat, 2002: 137).

Kemudian dalam hidup kehidupan di negara Kesatuan Republik Indonesia perlu adanya perlindungan konsumen juga disamping pembiayaan oleh konsumen. Biasanya dalam lalu lintas ekonomi, pelaku usaha konsumen adalah dua pihak yang saling membutuhkan. Pelaku usaha menjual produknya kepada konsumen, sedangkan konsumen membutuhkan barang yang dijual oleh pelaku usaha untuk memenuhi kebutuhannya sehingga kedua sama-sama memperoleh manfaat serta keuntungan. Namun, dalam prakteknya posisi tawar yang 
tidak seimbang antara konsumen dengan pengusaha sering kali merugikan konsumen. Praktek perdagangan yang merugikan konsumen diantaranya adalah penggunaan perjanjian baku dan pemuatan klausula eksonerasi secara tidak patut.

Bertitik tolaknya dari lemahnya kedudukan konsumen, maka pemerintah berkewajiban untuk melindungi konsumen. Untuk itu dalam rangka perlindungan terhadap konsumen telah dikeluarkan aturan mengenai perlindungan konsumen. Yakni Undang-Undang no. 8 tahun 1999 tetang perlindungan konsumen. Pasal 18 UndangUndang no. 8 tahun 1999 tetang perlindungan konsumen menyebutkan bahwa: 1.) pelaku usaha dalam menawarkan barang dan / atau jasa yang ditujukan untuk diperdagangkan dilarang membuat atau mencatumkan klausula baku pada setiap dokumen dan atau perjanjian apabila; a). Menyatakan pengalihan tanggung jawab pelaku usaha; b). Menyatakan bahwa pelaku usaha berhak menolak penyerahan kembali barang yang dibeli konsumen; c). Menyatakan bahwa pelaku usaha berhak menolak penyerahan kembali uang yang dibayarkan atas barang dan jasa yang dibeli oleh konsumen; d). Menyatakan pemberi kuasa dari konsumen kepada pelaku usaha baik secara langsung maupun tidak langsung untuk melakukan segala tindankan sepihak yang berkaitan dengan barang yang dibeli oleh konsumen secara angsuran; e). Mengatur perihal pembuktian atas hilangnya kegunaan barang atau pemanfaatan jasa yang dibeli oleh konsumen; f). Memberi hak kepada pelaku usaha untuk mengurangi manfaat jasa atau mengurangi harta kekayaan konsumen yang menjadi objek jual beli jasa; g). Menyatakan tunduknya konsumen kepada peraturan yang berupa aturan baru, tambahan lanjutan dan atau pengubahan lanjutan yang dibuat sepihak oleh pelaku usaha dalam masa konsumen memanfaatkan jasa yang dibelinya; $h$ ). Menyatakan bahwa konsumen memberikan kuasa kepada pelaku usaha untuk pembebanan hak tanggungan, hak gadai atau hak jaminan terhadap barang yang dibeli oleh konsumen secara angsuran. 2.) Pelaku usaha dilarang mencatumkan klausula baku yang letak atau bentuknya sulit terlihat atau tidak dapat di baca secara jelas atau yang pengungkapanya sulit dimengerti. 3.) setiap klausula baku yang telah ditetapkan oleh pelaku usaha pada dokumen atau perjanjian yang memenuhi ketentuan sebagaimana dimaksud pada ayat (1) dan ayat (2) dinyatakan batal demi hukum. 4.) pelaku usaha wajib menyesuaikan klausula baku yang bertentangan dengan undang-Undang ini.

Berdasarkan penjelasan pasal 18 ayat 1 undang-undang perlindungan konsumen, larangan ini dimaksudkan untuk menempatkan kedudukan kosumen setara dengan pelaku usaha berdasarkan prinsip kebebasan berkontrak. Sebagai konsekuensi atas pelanggaran terhadap ketentuan pasal 18 ayat 1 dan ayat 2 tersebut, kemudian pasal 18 ayat 3 undang-undang perlindungan konsumen, menyatakan batal demi hukum setip klausula baku yang telah ditetapkan oleh pelaku usaha pada dokumen atau perjanjian yang memuat ketentuan yang dilarang dalam pasal 18 ayat 1 dan ayat 2. Hal ini merupakan penegasan kembali sifat kebebasan berkontrak yang diatur dalam pasal 1320 KUHPerdata jo. Pasal 1337 KHUPerdata. Ini berarti klausula baku yang dimuat dalam perjanjian yang dilarang oleh pasal 18 ayat 2 dianggap tidak pernah ada karena batal demi hukum (Wijaya, 2003: 56).

Atas batalnya demi hukum dari suatu klausula sebagaimana disebutkan dalam pasal 18 ayat 3 , pasal 18 ayat 4 undang-undang perlindungan konsumen selanjutnya mewajibkan para pelaku usaha untuk menyesuaikan klausula baku yang bertentangan dengan undang-undang perlindungan konsumen. Pasal 45 undangundang perlindungan konsumen menentukan bahwa dalam hal terjadinya sengketa antara konsumen dengan pelaku usaha, sengketa tersebut dapat diselesaikan melalui pengadilan atau diluar pengadilan berdasarkan pilihan sukarela para pihak yang bersengketa. Penyelesaian sengketa ke pengadilan yakni dengan cara mengajukan gugatan yang kepengadilan baik secara individu, kelompok maupun gugatan yang dilakukan oleh lembaga perlindungan konsumen swadaya 
masyarakat (LPKSM) sedangkan penyelesaian sengketa diluar pengadilan dapat melalui Badan Penyelesaian Sengketa Konsumen (BPSK).

Selain dari hal diatas, ada juga jual beli angsuran. Salah satu sifat dari jual beli angsuran menurut sistem KUHPerdata adalah bahwa perjanjian jual beli itu hanya obligatoir saja. Ini berarti jual beli itu belum memindahkan hak milik ia baru meletakkan hak dan kewajiban timbal balik yaitu meletakkan kewajiban si penjual untuk menyerahkan hak milik atas barang yang dijualnya sekalugus pemberi hak untuk menuntuk pembayaran barang yang dijualnya. Sedangkan pembeli berkewajiban membayar barang serta berhak menuntut untuk menyerahkan hak milik atas barang yang dibelinya. Apa yang dikemukakan mengenai sifat jual beli ini nampak jelas dari pasal 1459 KUHPerdata yang menerangkan bahwa hak milik atas barang yang dijual tidaklah berpindah kepada si pembeli selama penyerahannya belum dilakukan (subekti, 1995: 11) sesuai dengan pasal 612 KUHPerdata maka penyerahan kebendaan bergerak tersebut dilakukan dengan penyerahan yang nyata akan kebendaan itu oleh atau atas nama pemilik atau dengan penyerahan kunci-kunci dari bangunan dalam mana kebendaan itu berada.

Dalam hal leavering atau penyerahan, KUHPerdata megandung sistem causal yaitu suatu sistem yang menggantungkan sahnya leavering itu pada dua syarat (subekti, 1995: 12) a.) sahnya titel yang menjadi dasar dilakukannya leavering; dan b.) leavering tersebut dilakukan oleh orang yang berhak berbuat bebas (beschikingsbevoegd) terhadap barang yang dileaver itu. Disini titel yang menjadi dasar leavering itu, yakni jual beli, tukar menukar, hibah (tiga perjanjian ini merupakan titel-titel untuk memindahkan hak milik ) adapun orang yang berhak berbuat bebas adalah pemilik barang sendiri atau orang yang dikuasakan olehnya. Selama ini pemahaman yang ada dimasyarakat mengenai jual beli angsuran, sewa beli dan leasing adalah sama yakni pembayarannya yang dilakukan secara berkala. Namun, pengertian antara jual beli angsuran, sewa beli dan leasing berbeda.

Pasal 1 huruf a Keputusan Menteri Keuangan Republik Indonesia no. 1169/KMK.01/1991 tentang Sewa Guna Usaha (leasing) memberikan devinisi leasing sebagai berikut:

$$
\text { Leassing adalah kegiatan }
$$

pembiayaan dalam bentuk penyediaan barang modal baik secara sewa guna usaha dengan hak opsi (finance lease) maupun sewa guna usaha tampa hak opsi (operating lease) untuk digunakan oleh lesse selama jangka waktu terntu berdasarkan pembayaran secara berkala.

Berdasarkan defini diatas jelas bahwa objek dari pembiayaan tersebut adalah barang modal atau alat produksi yang akan digunakan dalam kegiatan usaha. Selain itu bahwa didalam leasing hak milik atas ojek lease (barang modal) tetap berada pada leasor yakni pada perusahaan pembiayaan. Hak kepemilikan baru beralih pada leasse jika di ahir masa lease pihak lessee membeli dengan harga sisa (finance lease). Sedangkan keputusan Menteri perdagangan dan koperasi no. 34 / KP/ II / 1980 tentang perizinan kegiatan usaha sewa beli (hire purchase) jual beli angsuran dan sewa (renting) memberikan pengertian mengenai sewa beli dan jual beli angsuran sebagai berikut: a). Sewa beli (hire purchase) adalah jual beli barang dimana penjual melaksanakan penjualan barang dengan cara memperhitungkan setiap pembayaran yang dilakukan oleh pembeli dengan pelunasan atas harga barang yang telah disepakati bersama dan yang dikat dalam suatu perjanjian serta hak milik atas barang tersebut baru beralih dari penjual kepada pembeli setelah jumlah harganya dibayar lunas oleh pembeli kepada si penjual. b). Jual beli dengan angsuran adalah jual beli barang dimana penjual melaksanakan penjualan barang dengan cara menerima pelunasan pembayaran yang dilakukan oleh pembeli dalam beberapa kali angsuran atas harga barang yang telah disepakati bersama dan yang diikat dalam suatu perjanjian serta hak milik atas barang tersebut beralih dari penjual kepada pembeli pada saat barangnya diserahkan oleh penjual kepada pembeli. 
Sepintas, antara jual beli angsuran dengan sewa beli memang sama, yaitu pembayaran dilakukan secara bertahap, namun pada dasarnya antara kedua nya berbeda. Salah satu perbedaan yang mendasar adalah beralihnya hak milik. Dalam jual beli angsuran hak milik beralih pada pembeli setelah barang diserahkan sedangkan pada sewa beli hak milik itu tetap berada pada penjual selama belum dibayar lunas. Walaupun secara konseptual antara jual beli angsuran dan sewa beli memiliki perbedaan, namun dalam prakteknya keduanya hampir sama karena para pelaku usaha membuat klausul yang menyebabkan pembeli tidak diberi kebebasan untuk mengalihkan barang yang dibelinya secara angsuran atau sewa beli sebelum barang tersebut di bayar lunas. Pihak konsumen selalu dibebani kewajiban untuk menanggung segala resiko yang timbul pada banrang yang menjadi objek perjanjian.

Kemudian tentang jaminan fidusia, istilah fidusia berasal dari bahasa Belanda yaitu fiducie, sedangkan bahasa inggris disebut fiduciary tranfer or ownership, yang artinya kepercayaan. Dalam literatur, fiducia dikenal dengan istilah fiduciare eigendom overdracht (FEO) yaitu penyerahan hak milik berdasarkan atas kepercayaan. Di Indonesia, lembaga fiducia tumbuh melalui yurisprudensi dan kini telah mendapatkan pengakuan dalam undang-undang yaitu undang-undang no. 42 tahun 1999 tetang jaminan fidusia, yang selanjutnya dalam penulisan ini ditulis undang-undang fiducia. Keberadaan fiducia di Indoensia pertama kali diakui oleh yurisprudensi, berdasarkan keputusan hooggerchtshof batavia (HGH) tanggal 18 agustus 1932 tentang BPM-Clinet arrest. Lahirnya Arrest Hoge Raad tanggal 25 Januari 1929 tentang Bierbrouwerij Arrest (Negeri Belanda) sejak keputusan tersebut, fidusia mendapatkan pengakuannya secara jelas dalam yurisprudensi di Indonesia.

Pasal 1 angka 1 Undang-Undang Fidusia memberikan definisi mengenai fidusia sebagai berikut: fidusia adalah pengalihan hak kepemilikan suatu benda atas dasar kepercayaan dengan ketentuan bahwa benda yang hak kepemilikannya dialihkan tetap dalam penguasaan pemilik benda. Dari definisi fidusia yang diberikan UndangUndang Jaminan Fidusia dapat dikatakan bahwa dalam jaminan fidusia terjadi pengalihan hak kepemilikan. Pengalihan itu terjadi atas dasar kepercayaan dengan janji benda yang kepemilikannya dialihkan tetap dalam penguasaan pemilik benda.

Pasal 1 angka 1 Undang-Undang fidusia memberikan definisi mengenai jaminan fidusia sebagai berikut: "jaminan fidusia adalah hak jaminan atas benda bergerak baik yang berwujud maupun yang tidak berwujud dan benda tidak bergerak khususnya bangunan yang tidak dapat dibebani hak tanggungan sebagaimana dimaksud dalam Undang-Undang Nomor 4 Tahun 1996 tentang hak tanggungan yang tetap berada dalam penguasaan pemberi fidusia sebagai agunan bagi pelunasan utang tertentu yang memberikan kedudukan yang diutamakan kepada penerima fidusia terhadap kreditur lainnya".

Dari definisi yang diberikan diatas jelas bahwa fidusia dibedakan dengan jaminan fidusia "fidusia merupakan proses pengalihan hak kepemilikan, sedangkan jaminan fidusia adalah jaminan yang diberikan dalam bentuk fidusia". (Wijaya \& Yani, 2007: 130). Jika diperhatikan dengan pengalihan hak milik sebagaimana dimaksud dalam pasal 584 KUHPerdata jo. Pasal 612 ayat 1 KUHPerdata berbeda dengan pengalihan hak kepemilikan dalam jaminan fidusia.

Pasal 584 KUHPerdata menyatakan bahwa hak milik atas sesuatu kebendaan tak dapat diperoleh dengan cara lain, melainkan dengan pemilikan karena pelekatan, karena daluwarsa, karena pewarisan, baik menurut Undang-Undang maupun menurut surat wasiat dan karena penunjukan atau penyerahan berdasar atas suatu peristiwa perdata untuk memindahkan hak milik dilakukan oleh seorang yang berhak berbuat bebas terhadap kebendaan itu.

Dalam jaminan fidusia " pengalihan hak kepemilikan dimaksudkan semata-mata sebagai jaminan bagi pelunasan utang, bukan untuk seterusnya dimiliki oleh penerima fidusia. Ini merupakan inti dari pengertian jaminan fidusia yang dimaksud pasal 1 angka 
2 . bahkan sesuai dengan ketentuan pasal 33 Undang-Undang Fidusia bahwa setiap janji yang memberikan kewenangan kepada penerima fidusia untuk memiliki benda yang menjadi objek jaminan fidusia apabila debitur cedera janji akan batal demi hukum. Hal tersebut sesuai dengan Putusan Mahkamah

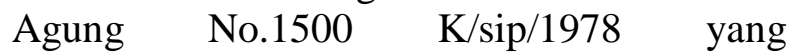
memutuskan bahwa kreditur tidak dianggap sebagai pemilik dari barang yang telah dijadikan jaminan fidusia oleh debitur tetapi kreditur hanya mempunyai hak preferen seperti halnya kreditur hipotek.

$$
\text { Jaminan fidusia merupakan }
$$

perjanjian ikutan (accessoir) dari suatu perjanjian pokok yaitu hutang-piutang. Sebagai suatu perjanjian accessoir, jaminan fidusia ini demi hukum hapus bila hutang pada perjanjian pokok, yang menjadi sumber lahirnya perjanjian penjaminan fidusia atau jamin dengan jaminan fidusia di hapus. Pasal 5 ayat 1 Undang-Undang fidusia menentukan bahwa pembebanan jaminan fidusia dibuat dengan akta notaris dalam bahasa Indonesia yang merupakan akta jaminan fidusia. Selain itu pasal 11 Undang-Undang fidusia juga mewajibkan benda yang dibebani dengan jaminan fidusia di daftarkan ke kantor pendaftaran fidusia yang berada di Kanwil Departemen Hukum dan Hak Asasi Manusia. Sebagai bukti bagi kreditur bahwa merupakan pemegang jaminan fidusia maka kantor pendaftaran fidusia akan menerbitkan sertifikat jaminan fidusia.

Sertifikat jaminan fidusia

mempunyai kekuatan eksekutorial yang dipersamakan dengan putusan pengadilan yang telah mempunyai kekuatan hukum tetap. Artinya bahwa sertifikat jaminan fidusia ini dapat langsung dieksekusi/dilaksanakan tampa melalui proses persidangan dan pemeriksaan melalui pengadilan dan bersifat final serta mengikat para pihak untuk melaksanakan putusan tersebut. Jaminan fidusia merupakan salah satu jaminan kebendaan yang memberikan hak mendahului untuk mengambil pelunasan dari debitur tanpa memperhatikan kreditur-kreditur lainnya ( droit de preference) hak preferren dari penerima fidusia tidak hilang walaupun debitur pailit. Ilmu hukum tidak membatasi kebendaan yang dapat dijadikan jaminan, hanya saja kebendaan yang dijaminkan tersebut haruslah merupakan milik dari pihak yang memberikan jaminan kebendaan tersebut. (Wijaya \& Yani, 2007: 80).

Eksekusi dari terhadap benda objek jaminan fidusia ini adalah melalui penjualan benda yang menjadi objek jaminan fidusia melalui pelelangan umum. Namun demikian berdasarkan ketentuan pasal 29 ayat 1 huruf c dalam hal penjualan melalui pelelangan umum diperkirakan tidak menghasilkan harga tertinggi yang menguntungkan pemberi fidusia ataupun penerima fidusia maka dimungkinkan penjualan dibawah tangan asalkan hal tersebut disepakati oleh para pihak. Berdasarkan ketentuan pasal 34 Undang-Undang fidusia dalam hal eksekusi jaminan fidusia ada dua kemungkinan dari hasil pelelangan atau penjualan barang jaminan fidusia yaitu: a). Hasil eksekusi melebihi nilai penjaminan, penerima fidusia wajib mengembalikan kelebihan tersebut kepada pemberi fidusia; b). Hasil eksekusi tidak mencukupi untuk pelunasan utang debitur atau pemberi fidusia tetap bertanggung jawab atas utang yang belum dibayar.

\section{KESIMPULAN}

Dengan memperhatikan sesuai uraian seluruh bagian-bagian yang mengatur tentang jaminan dan perlindungan konsumen maka Pengertian perjanjian yang terdapat dalam pasal 1313 KHUPerdata tersebut terlalu luas dan terlalu sempit. Pasal 1313 KUHPerdata dikatakan terlalu luas karena hanya menyebutkan perbuatan saja, misalnya zaakwarneming (pengurusan kepentingan orang lain), yang itu terjadi tampa diperjanjikan terlebih dahulu. Sedangkan yang menimbulkan perjanjian adalah perbuatan-perbuatan hukum yang akibatnya diatur oleh hukum. Selain itu kata perbuatan juga terlalu luas karena mencakup perbuatan yang bergerak dilapangan hukum harta kekayaan dan perkawinan yang tunduk pada ketentuan tersendiri bukan tunduk pada buku III KUHPerdata. Sehingga yang menentukan posisi siapa yang kuat dan atau pun lemah dalam perbuatan hukum tergantung pada yang 
membuat perjanjian. Olehnya demikian perusahaan pembiayaan jika para kreditur tidak melaksanakan hukum sesuai perjanjian akan berahir dengan pelelangan oleh perusahaan tersebut.

\section{DAFTAR PUSTAKA}

Kitab Undang-Undang Hukum Perdata

Mertokusumo, Sudikno. 1999. Mengenal Hukum (Suatu Pengantar). Liberty, Yogyakarta.

Peraturan Menteri Keuangan Nomor 84/PMK.012/2006 Tentang Perusahaan Pembiayaan.

Salim, HS. 2005. Perkembangan Hukum Jaminan Di Indonesia. Raja Grafindo Persada, Jakarta.

Subekti, R. 1990. Hukum Perjanjian. Intermasa, Jakarta.

Sunaryo. 2008. Hukum Lembaga Pembiayaan. Sinar Grafika, Jakarta.

Undang-Undang Nomor 42 Tahun 1999 Tentang Jaminan Fidusia.

Undang-Undang Nomor 8 Tahun 1999 Tentang Perlindungan Konsumen

Wijaya, Gunawan \& Yani, Ahmad. 2007. Jaminan Fidusia, Raja Grafindo Persada, Jakarta 